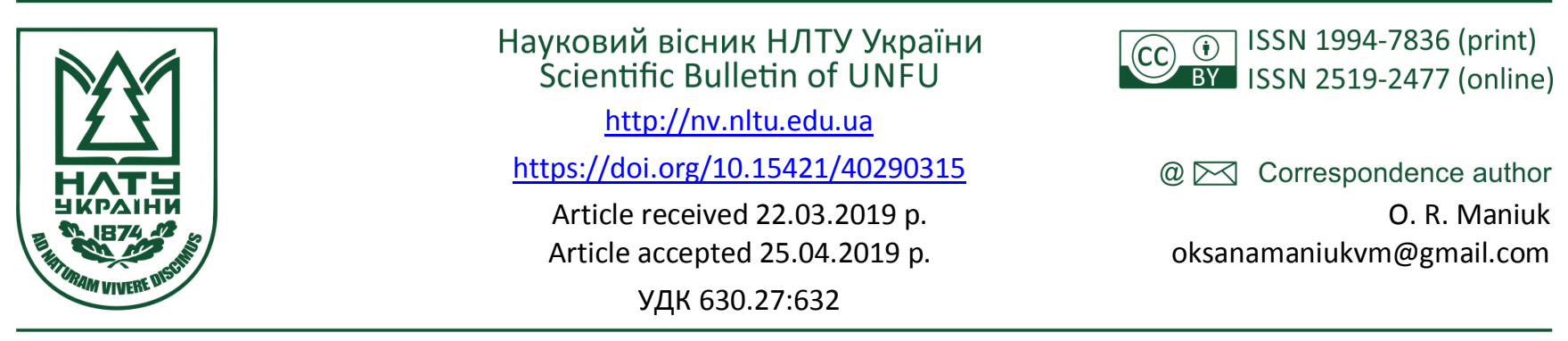

О. Р. Манюк, Ю. Д. Михайлюк, М. І. Манюк

Івано-Франківський національний технічний університет нафти і газу, м. Івано-Франківськ, Україна

\title{
ВПЛИВ ГАЛІТОВИХ ВІДХОДІВ КАЛІЙНИХ РОДОВИЩ ПРИКАРПАТТЯ НА ТЕХНОГЕННЕ ЗАСОЛЕННЯ ГРУНТІВ ТА ФІТОЦЕНОЗ
}

\begin{abstract}
Проаналізовано вплив галітових відходів Домбровського кар'єру Калуш-Голинського родовища калійних солей на грунти та рослинний покрив. Способом експериментальних досліджень на піддослідних ділянках у водяній витяжці визначено вміст: хлоридів - аргентометричним методом за Мором; іонів кальцію і магнію - тригонометричним методом; сульфатів турбідометричним методом; $\mathrm{pH}$ соляної витяжки - потенціометрично; суми поглинутих основ - за Каппеном; рухомого фосфору - за методом Кірсанова; гумусу - за Нікітином. Як індикатор стресової ситуації рослин використано концентрацію аскорбінової кислоти та катаклазу. Встановлено істотне олужнення грунтів, яке пов'язане з постійним поступленням і перерозподілом лужних іонів із солевідвалу. З'ясовано, що каталазна активність грунтових мікроорганізмів знижується під впливом засолення. Відзначено зменшення активності ферменту пропорційно концентрації хлорид-іону. Встановлено пригнічуючий вплив засолення на корінь рослин. Відзначено пропорційне зростання степені пригнічення на розвиток кореневої системи рослин із зростанням концентрації солей. Виявлено, що під впливом засолення відбувається гальмування біосинтезу фотосинтетичних пігментів. Встановлено, що у паростках пшениці спостерігається зниження вмісту аскорбінової кислоти залежно від рівня забруднення галітовими солями, оскільки аскорбінова кислота витрачається на інгибірювання вільних радикалів, які утворюються внаслідок забруднення.
\end{abstract}

Ключові слова: галітові відходи; фітоценоз; розсоли; довкілля.

Вступ. У процесі розроблення родовищ калійних солей утворюється значна кількість відходів, які зберігаються у хвостосховищах та кар'єрах і істотно впливають на довкілля. Так, проблему з накопичення розсолів із мінералізацією $180-350$ г·дм-3 і більше у хвостосховищах та безпосередньо в Домбровському кар'єрі КалушГолинського родовища калійних солей неодноразово порушували протягом останнього десятиліття на регіональному і державному рівнях та зазначали як одну 3 найактуальніших у Національній доповіді України про стан навколишнього природного середовища.

Сучасний стан об'єкта можна охарактеризувати як критичний, з огляду на: розвиток карстово-суфозійних процесів, збільшення дренуючого впливу прибічної частини кар'єру, ризик техногенного засолення оточуючих солевідвали грунтів та пригнічуючої дії на фітоценоз. Це становить загрозу безпеці життєдіяльності населення регіону, що й зумовлює високу актуальність досліджень, які ми здійснюємо.

Аналіз останніх досліджень і публікацій та формулювання цілей. Звичайно проблема впливу природного засолення на грунти та рослини сьогодні $є$ добре дослідженою. У більшості праць зазначено безпосеред- ню токсичну дію солей на рослини, на їхню життєдіяльність внаслідок порушення осмотичних процесів та мінерального живлення, вивчено механізми стійкості рослин соляному стресу. Водночас, питання техногенного засолення вивчено недостатньо, більшість праць стосується сольового забруднення довкілля при видобутку вуглеводнів (Miroshnicenko, 2002); Procko, 2010); Rudko \& Adamenko, 2001)). Наукові ж роботи, що стосуються вивчення впливу відходів калійного виробництва, $\epsilon$ відносно нечисельні та 3 урахуванням регіонального характеру екологічної проблеми здебільшого їх представляли фахівці науково-дослідних інститутів відповідного промислового регіону (Pavluk, Ferents \& Melko, 2013; Poberezna, 2015). У науковій літературі практично не розглянуто питання щодо специфічності дії саме галітових відходів на довкілля.

Отже, мета роботи - це вивчення та безпосередня оцінка впливу галітових відходів Домбровського кар'єру на грунти та рослинний покрив.

Матеріали та методи дослідження. У водяній витяжці ми визначали вміст:

- хлоридів - аргентометричним методом за Мором;

- іонів кальцію і магнію - тригонометричним методом;

\section{Інформація про авторів:}

Манюк Оксана Романівна, канд. геолог. наук, доцент, кафедра екологіï. Email: oksanamaniukvm@gmail.com

Михайлюк Юлія Дмитрівна, канд. техн. наук, доцент, кафедра екологіï. Email: umiha23@gmail.com; https://orcid.org/0000-0003-2448-3847

Манюк Михайло Іванович, канд. геолог. наук, доцент, кафедра геології та розвідки нафтових і газових родовищ. Email: manukomv@i.ua

Цитування за ДСтУ: Манюк О. Р., Михайлюк Ю. Д., Манюк М. І. Вплив галітових відходів калійних родовищ Прикарпаття на техногенне засолення ґрунтів та фітоценоз. Науковий вісник НЛтУ України. 2019, т. 29, № 3. С. 71-75.

Citation APA: Maniuk, O. R., Mykhailiuk, Yu. D., \& Maniuk, M. I. (2019). The influence of galite wastes of potassium deposits of the Precarpathians on technogenic salinization of soils and phytocoenosis. Scientific Bulletin of UNFU, 29(3), 71-75. https://doi.org/10.15421/40290315 
- сульфатів - турбідометричним методом;

- $\mathrm{pH}$ соляної витяжки - потенціометрично;

- суми поглинутих основ - за Каппеном;

- рухомого фосфору - за методом Кірсанова;

- гумусу - за Нікітином.

Викладення основного матеріалу. На Калуш-Голинському родовищі калійних солей поширений рівнинний тип хвостосховищ i акумулюючих басейнів, площі яких змінюються у широких межах, а глибина від 5-10 м до 30-50 м. Нагнітання відходів відбувалось гідравлічним методом у вигляді пульпи, яка в процесі складування диференціювалась: із неї осідала тверда складова, а освітлені розсоли використовували для зворотнього водопостачання. Дамби, які обмежують басейни та хвостосховища, споруджували із місцевих природних матеріалів (пісків, суглинків) або 3 відходів - хвостів і шламів.

Відходи від пробки високомінералізованих калійних руд складувались у хвостосховища № 1 і № 2 (рисунок). Відповідно на концерні ДП "Калійний завод" ВАТ "Оріана" зайнята хвостосховищами площа становить 130 га. За 25 років експлуатації в них накопичено близько 10 млн м ${ }^{3}$ твердих та рідких відходів. Розсоли хвостосховища насичені сульфатними та хлоридними солями із загальною мінералізацією 350 г/л. Характеристику ареалів засолення підземних вод у межах Калуш-Голинського родовища калійних солей представлено у табл. 1.

Табл. 1. Характеристика ареалів засолення підземних вод у межах Калуш-Голинського родовища калійних солей

\begin{tabular}{|c|l|c|c|c|}
\hline $\begin{array}{c}\text { № } \\
\text { 3/п }\end{array}$ & \multicolumn{1}{|c|}{ Джерело засолення } & $\begin{array}{c}\text { Площа ареалу } \\
\text { засолення, га }\end{array}$ & $\begin{array}{c}\text { Мінералізація вод, } \\
\text { г/л }\end{array}$ & Тип води (за Курніковим-Валяшко) \\
\hline 1 & Хвостосховище № 1 & 150 & $10,6-54,3$ & сульфатний, підтип натрієвий \\
\hline 2 & Акумулюючий басейн Домбровського кар'єру & 24 & $58,6-86,3$ & сульфатний, підтип натрієвий \\
\hline 3 & Солевідвал № 1 & 50 & $1,8-9,6$ & сульфатний, підтип магнієвий \\
\hline 4 & Солевідвал № 4 & 25 & $1,5-27,9$ & сульфатний, підтип натрієвий \\
\hline 5 & Шламосховище дослідно-промислової фабрики & 30 & $20,0-37,4$ & сульфатний, підтип магнієвий \\
\hline 6 & "Галда" хімічної фабрики шахти "Калуш" & 6,7 & $1,2-4,1$ & сульфатний, підтип натрієвий \\
\hline 7 & $\begin{array}{l}\text { Смності з концентро-ваними розсолами на } \\
\text { проммайданчику шахти "Калуш" }\end{array}$ & 1,2 & $10-140$ & сульфатний, підтип магнієвий \\
\hline
\end{tabular}

Отже, в межах Калуш-Голинського родовища калійних солей на земній поверхні складувались тверді та рідкі відходи від перероблення калійних руд, а також розкривні соленосні породи Домбровського кар'єру та розсоли, які утворені внаслідок вилуговування атмосферними опадами виступів кар'єру.

Вагомий вплив на гідрохімічний режим поверхневих вод під час відкритого розроблення мають розкривні породи Домбровського кар'єру, представлені легкорозчинними соленосними глинами. Вміст хлористого натрію в породах сягає 70 \%. Захоронення порід проводиться у відвали заввишки 50 м. Загальна площа солевідвалів сягає 82,4 га. Сьогодні у відвали відкладено близько 40 млн т порід.

За нашими дослідженнями, у хвостосховищах та солевідвалах існують три види розсолів:

- розсоли вилуговування, які утворюються внаслідок водноерозійних процесів, зумовлених високим ступенем розчинення атмосферними опадами соленосних порід, які складують у відвал. Це зумовлює значну мінералізацію поверхневого стоку із солевідвалів, який проявляється у вигляді джерел і навіть струмків. Інтенсивність водно-ерозійних процесів має сезонний характер. Встановлено, що внаслідок розчинення вмісту солевідвалів Домбровського кар'єру атмосферними опадами утворюється близько 300 тис. м $^{3}$ розсолів вилуговування на рік із мінералізацією 250 г/л;

- розсоли конденсаційного походження, що утворюються на поверхні солевідвалів внаслідок конденсації вологи, яка насичується легкорозчинними солями за певних змін температури і вологості. За даними досліджень, впродовж однієї доби за температури повітря $+17-19{ }^{\circ} \mathrm{C}$ і відносної вологості 92-95 \% на поверхні монолітної солі конденсується близько 0,25 мм вологи. Отож, кількість конденсаційних розсолів, утворених у солевідвалах, становить $45000 \mathrm{~m}^{3} /$ рік; мінералізація розсолів - 260-300 г/л;

- розсоли, які утворюються під дією ущільнення розкривних порід. У відвалах заскладовано 40 млн м ${ }^{3}$ соленосних глин, 3 яких витіснено близько 20 тис. м ${ }^{3}$ розсолів; вміст солей у розсолах становить 320-370 г/л.

Встановлено, що солевідвали є необмеженим джерелом засолення підземних, i, в першу чергу, поверхневих вод. Підраховано, що із 370 тис. м $^{3}$ розсолів, які утворилися в тілі солевідвалів, близько 100 тис. м ${ }^{3}$ потрапляє в поверхневі та підземні води, утворюючи ареали засолення. При цьому площа ареалів становить 25-50 га. Освітлені розсоли хвосто- і шламосховищ калійного родовища $є$ високомінералізованими з'єднаннями, переважно хлоридно-натрієвого складу, 3 мінералізацією 200-380 г/л, основний вміст іонів якого наведено у табл. 2.

Табл. 2. Фізико-хімічна характеристика розсолів Домбровського кар'єру Калуш-Голинського родовища калійних солей

\begin{tabular}{|c|c|c|c|c|c|c|}
\hline Густина & \multicolumn{5}{|c|}{ Вміст іонів, г/л } & Мінералі- \\
\cline { 2 - 7 }$\rho \cdot 10^{3} \mathrm{\kappa} / \mathrm{M}^{3}$ & $\mathrm{~K}^{+}$ & $\mathrm{Mg}^{2+}$ & $\mathrm{Na}^{+}$ & $\mathrm{Cl}^{-}$ & $\mathrm{SO}_{4}{ }^{2-}$ & зація, $/$ л \\
\hline 1,237 & 28,30 & 22,03 & 76,20 & 177,12 & 46,45 & 350,10 \\
\hline
\end{tabular}

Повний хімічний аналіз високомінералізованих розсолів Домбровського кар'єру свідчить, що розсоли мають такі фізико-хімічні характеристики:

- густина - 1237 кг $/ \mathrm{m}^{3}$;

- мінералізація - 350,10 г/л;

- показник, $\mathrm{pH}-6,2$;

- механічні домішки - 35 мг/л;

- сульфат іон - 46,44 г/л;

- хлор іон - 177,12 г/л;

- магній - 22,03 г/л;

- кальцій - 0,01 г/л;

- натрій і калій сумісно - 104,05 г/л;

- тип води - хлоридно-натрієво-сульфатний.

Основними компонентами забруднення є, відповідно, хлориди і сульфати натрію та калію. Забруднювальні компоненти піддаються вітровому розсіюванню, дифузійній і фільтраційній міграції, засолюючи геологічне середовище.

Вітрова ерозія солей з поверхні солевідвалів і шламосховищ та пилогазові викиди впливають здебільшого на грунти. Розсіювання солей відбувається відповідно до напрямку вітрів на відстань 2-4 км від джерела забруднення. Солі накопичуються у верхньому рослинному шарі, товщина якого може сягати до 0,02 м. На територіях, які піддалися впливу вітрового забруднення, 
вміст солей підвищується у 4-10 разів. Особливо негативно впливає діяльність калійних підприємств на гідрохімічний режим поверхневих і підземних вод.

Складування і відкрите зберігання на земній поверхні легкорозчинних галітових відкладів в умовах вологого клімату супроводжується постійним утворенням у солевідвалах і хвостосховищах високомінералізованих (до 350 г/л) розсолів, що характеризуються високою міграційною здатністю і змінюють гідрохімічний режим поверхневих та підземних вод. Так, із західного боку Домбровського хвостосховища внаслідок фільтрації розсолів через некеровану основу хвостосховища у водоносному горизонті утворився великий ареал засолення, мінералізація підземних вод у якому збільшилася, порівняно 3 фоновою, в десятки разів і досягла 15,5 г/л.

Ареали засолення розширюються здебільшого в напрямку потоку підземних вод і діючих водозаборів, що розміщені поблизу джерел забруднень. Через селективну виїмку сильвінітових руд посилюється загроза засолення підземних вод, оскільки тут відбувається значне осідання земної поверхні з утворенням водопровідних тріщин.

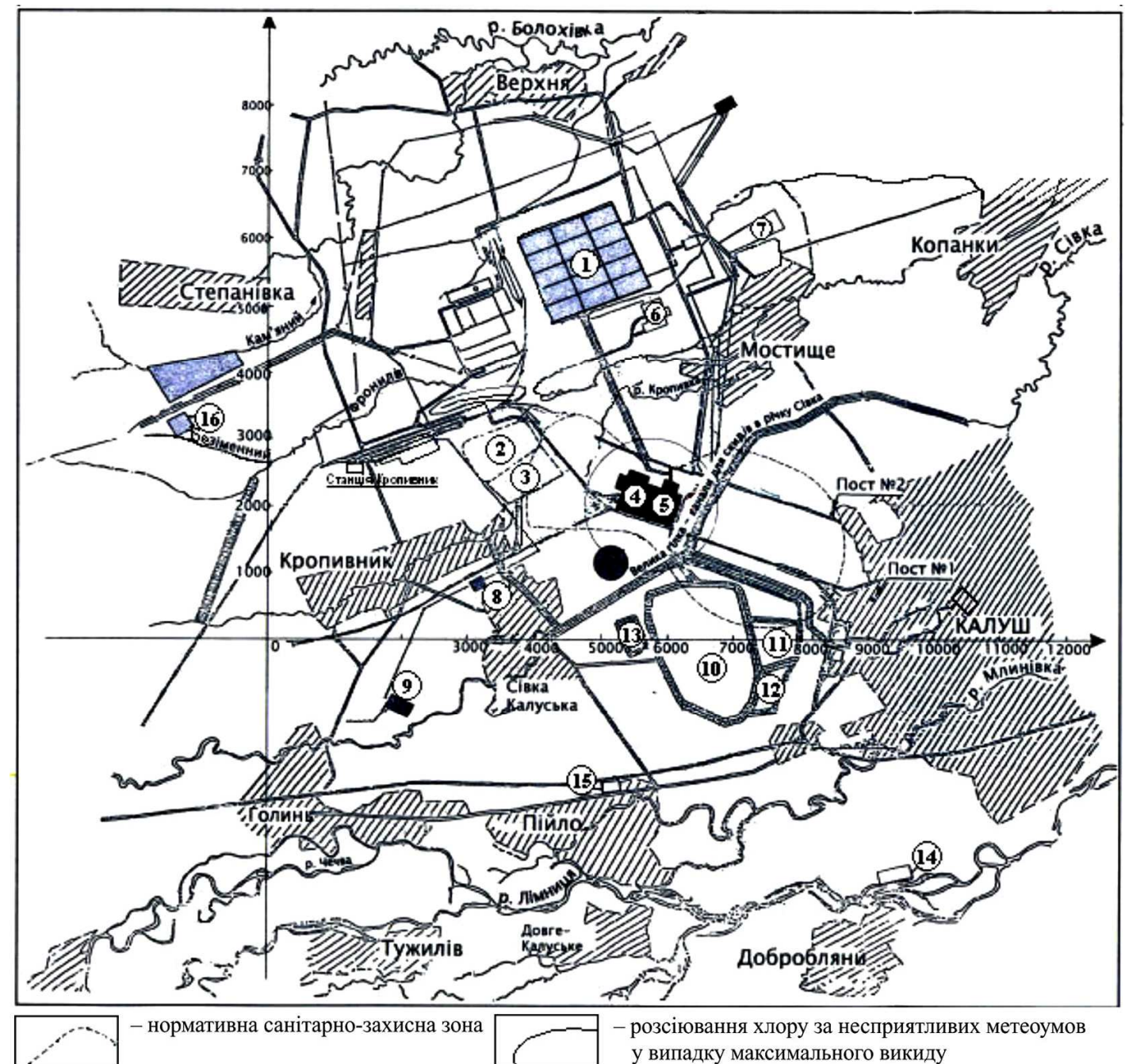

Рисунок. Карта розташування джерел забруднення калійних виробництв Калуського промислового району. Масштаб 1:95000: 1) майданчик хімічного виробництва; 2) хвостосховище № 2; 3) хвостосховище № 3; 4) хімфабрика; 5) магнієвий завод; 6) ТЕЦ; 7) золошлаковідвал; 8) шахта "Нова Голинь"; 9) майданчик головного та допоміжного створів копальні; 10) Домбровський кар'єр; 11) відвал № 1; 12) відвал № 4; 13) акумулюючий басейн; 14) господарсько-питний водозабір на р. Лімниця; 15) водосховище для водопостачання на р. Чечва

Як показали результати проведених досліджень, у цьому регіоні розвинуті лучні, лучно-болотні, болотні та дернові грунти. Лучні грунти утворились під лучною трав'яною рослинністю на алювіальних відкладах річкових заплав в умовах високого (2-3 м) стояння рівня грунтових вод. Лучні грунти потрапляють під вплив тривалого затоплення паводковими водами. Грунтоутворення тут ускладнюється акумуляцією алювіального матеріалу. У місцях, де відбувається нашарування делювію та елювію, вони шаруваті й мають добре розвинений, але погано диференційований профіль. Гумусовий горизонт сягає глибини 20-40 см. Він є темно-сірого кольору, дрібно-зернистої структури, ущільнений.
До глибини 60-100 см простягається перехідний горизонт темно-сірого кольору з буруватим відтінком, горіхоподібної структури, вологий, ущільнений, у нижній частині слабко оглеєний. Нижче залягає оглеєна материнська порода - алювіальні відклади різного механічного складу, часто шаруваті.

У лучних грунтах міститься у середньому $3,1 \%$ перегною. Гідролітична кислотність - невисока - в середньому близько 3 мг-екв. на 100 г грунту. Сума увібраних основ досягає 12,6 мг-екв. на 100 г грунту, а ступінь насичення основами - 80 \%. Вони мають середні запаси рухомих форм поживних для рослин елементів. Лучні грунти мають досить високу природну родючість. 
Лучно-болотні грунти залягають у днищах балок та заплавах річок і потоків. Формування їх відбувається в умовах постійного надмірного зволоження грунтовими i поверхневими водами. Грунтові води залягають на глибині 0,5-1,5 м. 3 огляду на це, тут повністю оглеєний перехідний горизонт. Грунти мають високу потенційну родючість. У верхньому горизонті вони містять у середньому 5,3\% гумусу, часто до $8 \%$. Реакція грунтового розчину слабокисла, гідролітична кислотність невисока.

Болотні грунти займають найбільш низькі рівні заплав та днищ балок. Утворились вони в умовах постійного перезволоження неглибоко (0,3-0,6 м) залягаючими грунтовими водами, внаслідок чого весь їхній профіль має виразні ознаки намулення. Дернові - це слабкорозвинені грунти прирічкових частин заплав, складені наймолодшим сучасним алювієм, слабкозадерновані піски, дернові опідзолені грунти на спадистих та крутих схилах.

Для проведення досліду ми відібрали окультурені лугові грунти та 3 метою встановлення засоленості грунту та фітоценоз використано галітові відходи 3 Домбровського кар'єру. Як тест-об'єкт використали зерна пшениці з доброю врожайністю (порядку 98 \%). Ці зерна висаджували в пластикові контейнери. Вони вирощувались за цілодобового освітлення і кімнатної температури впродовж 14 днів. Їх щоденно підливали, доводячи грунт до повної вологоємності.

Дослід проводили щодо дослідження зростання зерна, росту і розвитку зерен пшениці на фоні забруднення грунту галітовими відходами. Так, по периметру Домбровського кар'єру ми заклали три піддослідних ділянки розміром $10 \times 10$ м на віддалі $50,100,500$ м від тіла дамби. Як індикатор стресової ситуації рослин використали концентрацію аскорбінової кислоти та катаклазу. Відповідно результати аналізу грунтових зразків, які були відібрані поблизу кар'єру, представлено в табл. 3 та 4.

Табл. 3. Агрохімічні показники грунту

\begin{tabular}{|c|c|c|c|}
\hline \multirow{2}{*}{ Показник } & \multicolumn{3}{|c|}{ Віддаль від границі солевідвалу, м } \\
\cline { 2 - 4 } & 50 & 100 & 500 \\
\hline $\mathrm{pH}_{\text {КСІ }}$ & $8,19^{ \pm 0,02}$ & $6,38^{ \pm 0,01}$ & $7,84^{ \pm 0,01}$ \\
\hline Нг, мг-екв/100 г грунту & 0,23 & $0,37^{ \pm 0,3}$ & 0,23 \\
\hline $\mathrm{S}$, мг-екв/100 г грунту & $43,2^{ \pm 0,5}$ & $18,5^{ \pm 0,8}$ & $48,3^{ \pm 0,1}$ \\
\hline Гумус, \% & $0,9^{ \pm 0,1}$ & $1,3^{ \pm 0,1}$ & $4,1^{ \pm 0,1}$ \\
\hline $\mathrm{P}_{2} \mathrm{O}_{5}$, мг/кг грунту & $25,5^{ \pm 0,5}$ & $37,8^{ \pm 0,6}$ & $87,6^{ \pm 1,0}$ \\
\hline
\end{tabular}

Табл. 4. Результати аналізу водяної витяжки проб грунту

\begin{tabular}{|c|c|c|c|}
\hline Показник & \multicolumn{3}{|c|}{ Віддаль від границі солевідвалу, м } \\
\hline $\begin{array}{c}\text { Концентрація, мг- } \\
\text { екв/100 г грунту: }\end{array}$ & 50 & 100 & 500 \\
\hline $\mathrm{Ca}^{2+}$ & $1,8^{ \pm 0,3}$ & $0,8^{ \pm 0,3}$ & $1,3^{ \pm 0,3}$ \\
\hline $\mathrm{Mg}^{2+}$ & 0,5 & $1,5^{ \pm 0,6}$ & $1,3^{ \pm 0,3}$ \\
\hline $\mathrm{SO}_{4}^{2-}$ & $0,034^{ \pm 0,004}$ & $0,037^{ \pm 0,004}$ & - \\
\hline $\mathrm{Cl}^{-}$ & $0,33^{ \pm 0,06}$ & $0,27^{ \pm 0,06}$ & $0,35^{ \pm 0,06}$ \\
\hline
\end{tabular}

Відповідно реакція грунтового розчину на віддалі 50 м від межі солевідвалу - лужна, на віддалі 100 мнейтральна, а на віддалі 500 м - слаболужна. На нашу думку, таке олужнення пов'язане 3 постійним поступленням і перерозподілом лужних іонів із солевідвалу.

Значення гідролітичної кислотності в досліджуваних зразках максимальне на віддалі 100 м від границі солевідвалу і сягає 0,37 мг-екв/100 г грунту. Найбільше значення поглинутих основ спостерігали на віддалі 50 та 500 м і сягає відповідно 43,2 та 48,3 мг/100 г грун- ту. При тому, що на віддалі 100 м від солевідвалу цей показник у два 2-2,5 раза менший.

Досліджуваний грунт характеризується досить низьким вмістом гумусу, як було зазначено раніше. Можливо, що накопичення гумусу на цій території слабо виражене через відносну геологічну "молодість" відкладів і пов'язане $з$ дією солей на мікробіологічний комплекс грунту. Відповідний вміст рухомих форм фосфору змінюється відповідно до зміни гумусу.

Концентрація іонів кальцію на віддалі 50 м від гранці солевідвалу максимальна, що пояснюємо вітровим переносом частинок галітових відходів. Вміст магнію у досліджуваних зразках характеризується як дуже низький на віддалі 50, 100 м, та середній на віддалі 500 м.

Водночас як вміст сульфатів у грунті не відрізняється від віддалі і не перевищує гранично допустимої концентрації. За вмістом хлорид-іонів ділянки на 50, 100, 500 м характеризуються як слабозасолені. Як уже було зазначено раніше, ділянки території, які прилягають до солевідвалу, представлені луговим фітоценозом. При цьому кількість рослин зменшується з віддаленням від границі солевідвалу, проте фіксується істотне зростання їхніх розмірів (табл. 5).

Табл. 5. Характеристика фітоценозів у районі впливу солевідвалу

\begin{tabular}{|c|c|c|c|}
\hline \multirow{2}{*}{ Показник } & \multicolumn{3}{|c|}{ Віддаль від границі солевідвалу, м } \\
\hline & 50 & 100 & 500 \\
\hline $\begin{array}{l}\text { Загальна кількість } \\
\text { виявлених видів }\end{array}$ & 17 & 17 & 18 \\
\hline Проектне покриття, \% & 70 & 80 & 90 \\
\hline $\begin{array}{l}\text { Загальна щільність } \\
\text { насаджень, екземп./м² }\end{array}$ & 146 & 106 & 86 \\
\hline Середня висота, см & 58,5 & 66,3 & 77,3 \\
\hline Дом & \begin{tabular}{|c|} 
Calamagros- \\
tis epigeios \\
Roth
\end{tabular} & $\begin{array}{l}\text { Dactylis } \\
\text { glomerata }\end{array}$ & $\begin{array}{c}\text { Calamagros- } \\
\text { tis epigeios } \\
\text { Roth }\end{array}$ \\
\hline
\end{tabular}

За результатами досліду видно, що каталазна активність грунтових мікроорганізмів знижується під впливом засолення. Зменшення активності ферменту відбувається пропорційно концентрації хлорид-іону. Відповідно можна вважати, що каталазна активність $є$ добрим індикатором рівня засолення грунту (табл. 6).

Табл. 6. Активність каталази і дихання грунту після завершення досліду

\begin{tabular}{|c|c|c|c|}
\hline Варіант & $\begin{array}{c}\text { Концентрація } \\
\mathrm{CI}^{-}, \text {г/кг грун- } \\
\text { ту }\end{array}$ & $\begin{array}{c}\text { Активність ка- } \\
\text { талази, мл } \mathrm{O}_{2} / 1 \text { г } \\
\text { грунту }\end{array}$ & $\begin{array}{c}\text { Дихання, мг } \\
\mathrm{CO}_{2} / 10 \text { г грунту }\end{array}$ \\
\hline Контроль & - & 1,4 & 77,0 \\
\hline \multirow{2}{*}{$\begin{array}{c}\text { С у складі } \\
\text { галітових } \\
\text { відходів }\end{array}$} & 0,1 & 1,0 & 67,8 \\
\cline { 2 - 4 } & 0,2 & 0,8 & 55,4 \\
\cline { 2 - 4 } & 0,5 & 0,6 & 49,3 \\
\hline
\end{tabular}

Дихання грунту є інтегральним показником роботи всієї біоти. Відповідно аналіз результатів проведених досліджень дав можливість стверджувати про істотне зниження активності самоочищувальних процесів у грунті під дією галітових солей. Так, дихання грунту в концентрації хлоридів у складі галітових відходів 1,0 г/кг грунту зменшується у 2,2 раза, порівняно з незасоленим грунтом контрольного взірця.

Водночас результати вивчення впливу забруднення грунту галітовими відходами на динаміку проростання пшениці показав, що знижену енергію проростання зерен спостерігаємо у всіх варіантах досліду, порівняно 3 контрольним зразком. Водночас проростання зерен було пропорційне до рівня вмісту сольового забруднення. Найбільшу в контролі 100 \%, найменшу спостерігали за 
вмісту хлориду в складі галітових відходів 1,0 г/кг грунту $(86 \%)$. За результатами виміру висоти надземної частини рослин було виявлено неістотний стимулювальний ефект концентрації хлориду у складі галітових відходів 0,1-0,2 г/кг грунту на 5 і 1,7 \%, порівняно 3 контрольним зразком. Проте під час зростання концентрації вище від наведеної спостерігаємо пригнічення росту рослин пропорційно зростанню засоленості грунту.

У всіх варіантах досліджень виявили пригнічуючий вплив засолення на сам корінь рослини. Так, відзначаємо пропорційне зростання степені пригнічення на розвиток кореневої системи рослин із зростанням концентрації солей. При цьому зміна довжини коренів істотна (табл. 7).

Табл. 7. Динаміка розвитку коренів під впливом засоленості

\begin{tabular}{|c|c|c|c|c|}
\hline \multirow[t]{2}{*}{ Варіант } & \multirow{2}{*}{$\begin{array}{l}\text { Концентра- } \\
\text { ція СI, г/кг } \\
\text { грунту }\end{array}$} & \multirow{2}{*}{$\begin{array}{c}\text { Довжина, } \\
\text { мм }\end{array}$} & \multicolumn{2}{|c|}{$\begin{array}{c}\text { Варіювання }( \pm) \\
\text { до контролю }\end{array}$} \\
\hline & & & MM & $\%$ \\
\hline Контроль & & 182 & - & - \\
\hline \multirow{4}{*}{$\begin{array}{c}\mathrm{CI}^{-} \text {у складі } \\
\text { галітових } \\
\text { відходів }\end{array}$} & 0,1 & 181 & -1 & $-0,5$ \\
\hline & 0,2 & 175 & -7 & $-3,8$ \\
\hline & 0,5 & 167 & -15 & $-8,2$ \\
\hline & 1,0 & 145 & -37 & $-20,3$ \\
\hline
\end{tabular}

Водночас у контрольному зразку корені 100 \% мали типову овально-конусоподібну форму із слаборозвиненими кореневими волосками. Тоді як унаслідок забруднення галітовими відходами у більшості коренів форма кінчика загострено-конусоподібна, при цьому у всіх варіантах відзначаємо розвиток кореневих волосків, при цьому їх збільшення відбувалось пропорційно із зростанням концентрації солей. Ймовірно, утворення значної кількості кореневих волосків, на нашу думку $є$ своєрідним компенсатором відставання росту коренів унаслідок засолення і є своєрідним джерелом додаткового поступлення води й елементів живлення.
Засолення грунтів впливає не тільки на ріст та розвиток рослин, але й на протікання біохімічних реакцій. Під впливом засолення відбувається гальмування біосинтезу фотосинтетичних пігментів. Так, вміст хлорофілу у піддослідних пшеницях був нижчим, ніж у контрольному зразку. Водночас як зменшення концентрації пігментів $є$ пропорційний зростанню концентрації солей. Варто відзначити, що у паростках пшениці спостерігали зниження вмісту аскорбінової кислоти залежно від рівня забруднення, оскільки аскорбінова кислота витрачається на інгибірювання вільних радикалів, які утворюються під час забруднення.

Висновок. Отже, можна стверджувати, що всі показники як морфологічні, так біохімічні, які ми вивчали, мають високу біондикаційну цінність, оскільки їхня динаміка відповідає відповідній концентрації забрудника.

\section{Перелік використаних джерел}

Miroshnicenko, M. M. (2002). Influence of contamination oil is on property of soils of different grain-size distribution. Bulletin of $\mathrm{Ag}$ rarian Science, 10, 52-54. [In Ukrainian].

Pavluk, Yu. E., Ferents, V. M., \& Melko, V. M. (2013). Technogenic danger of mining of potassium mineral fertilizers. Bulletin of Lviv State University of Life Safety, 7, 199-2002. [In Ukrainian].

Poberezna, L. Ya. (2015). Complex estimation of ecological risk of territories adherent to the district of development of Kalush-Holunskiy deposit of potassium salt. Bulletin of the Kremenchug Mykhaylo Ostrogradsky National University, 3(1), 150 156. [In Ukrainian].

Procko, Ya. I. (2010). Influence of oil and oil products is on soil cover. Bulletin of the Poltava State Agrarian Academy, 2, 189-194. [In Ukrainian].

Rudko, G. I., \& Adamenko, O. M. (2001). Ecological monitoring of geological environment. Lviv: Lviv Ivan Franko National University, 260 p. [In Ukrainian].

O. R. Maniuk, Yu. D. Mykhailiuk, M. I. Maniuk Ivano-Frankivsk National Technical University of Oil and Gas, Ivano-Frankivsk, Ukraine

\section{THE INFLUENCE OF GALITE WASTES OF POTASSIUM DEPOSITS OF THE PRECARPATHIANS ON TECHNOGENIC SALINIZATION OF SOILS AND PHYTOCOENOSIS}

The influence of galite wastes from the Dombrovskii quarry of Kalush-Golinsky deposit of potassium salts on soils and vegetation cover is analyzed. By means of experimental research in the water extract of experimental plots the content of the following parameters are determined: chlorides - by the argentometric Mohr method; calcium ions and magnesium- by trigonometric method; sulfates - by turbidimetric method; $\mathrm{pH}$ of the salt extract - potentiometrically; the amount of absorbed bases by Kappen's method; mobile phosphorus- by Kirsanov's method; humus - by Nikitin's method. The concentration of ascorbic acid and catalase is used as an indicator of the plant stressful situation. It is defined that the investigated soil is characterized by low content of humus and is caused by the action of gallic salts on its microbiological complex. Significant soil alkalification has been revealed, which is associated with the constant receipt and redistribution of alkaline ions from salt dissolution. It is found that catalase activity of soil microorganisms decreases under the influence of salinity. Reduced enzyme activity is proportional to the concentration of chlorideion. The analysis of the conducted studies results made it possible to confirm the significant decrease of self-healing processes activity in the soil under the influence of galite salts. The depressive effect of salinization on plant roots is defined. There is a proportional increase in the degree of inhibition on the development of the plant root system with salt concentration increase. It has been revealed that soil salinization affects not only the growth and development of plants, but also the course of biochemical reactions. It is also found that under the influence of salinization the biosynthesis of photosynthetic pigments is inhibited. It has been established that there is a decrease in the content of ascorbic acid in wheat grown depending on the level of contamination with galite salts, since ascorbic acid is used to inhibit free radicals that are formed during contamination. In general, the results of the conducted research show that the indicators studied such as morphological and biochemical, have high bioindicative value since their dynamics corresponds to the appropriate concentration of the pollutant.

Keywords: galite wastes; phytocenosis; brines; environment. 